慶應義塾大学学術情報リポジトリ

Keio Associated Repository of Academic resouces

\begin{tabular}{|c|l|}
\hline Title & $\begin{array}{l}\text { Transient inhibition of BMP signaling by Noggin induces cardiomyocyte differentiation of mouse } \\
\text { embryonic stem cells }\end{array}$ \\
\hline Sub Title & ノギンによるBMPシグナルの一過性の抑制はマウス胚性幹細胞を心筋細胞に分化させる \\
\hline Author & 湯浅, 慎介(Yuasa, Shinsuke) \\
\hline Publisher & 慶應医学会 \\
\hline Publication year & 2005 \\
\hline Jtitle & 慶應医学 (Journal of the Keio Medical Society). Vol.82, No.4 (2005. 12),p.7- \\
\hline JaLC DOI & \\
\hline Abstract & \\
\hline Notes & 号外 \\
\hline Genre & Journal Article \\
\hline URL & https://koara.lib.keio.ac.jp/xoonips/modules/xoonips/detail.php?koara_id=AN00069296-2005120 \\
& 2-0007 \\
\hline
\end{tabular}

慶應義塾大学学術情報リポジトリ(KOARA)に掲載されているコンテンッの著作権は、それぞれの著作者、学会または出版社/発行者に帰属し、その権利は著作権法によって 保護されています。引用にあたっては、著作権法を遵守してご利用ください。

The copyrights of content available on the KeiO Associated Repository of Academic resources (KOARA) belong to the respective authors, academic societies, or publishers/issuers, and these rights are protected by the Japanese Copyright Act. When quoting the content, please follow the Japanese copyright act. 


\title{
Transient inhibition of BMP signaling by Noggin induces cardiomyocyte differentiation of mouse embryonic stem cells
}

\author{
(ノキンによるBMPシグナルの一過性の抑制はマウス肧性幹細胞を心筋紐胞に分化させる)
}

\section{湯 浅 㥀介}

\section{内容の要旨}

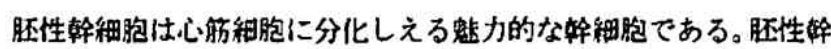

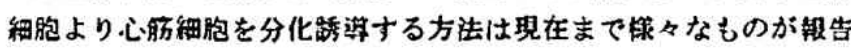
されているが、そのとれも润足のいくものではない。眼性蛀細胞の分

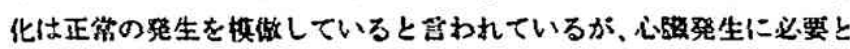
されている因子を加えただけては辡率には分化しえないと田われて いる。心肪細胞の発生仕全身の政器の中でも最も早期、すなわち原胆 陷入が始まり三胚葉が形成され始めるマウスの胎生7.0日目に始ま る。心肪細胞の初期発生における低要な因子は過去に栐々なものが報 告されており、BMP (Bone morphogenic protein)、Wnt, FGF (Fibroblast growth factor)， IGF-1 (Insulin like growth factor-1) などがあるが、これ

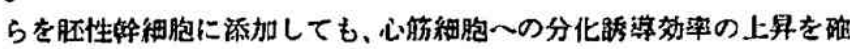
叉しえなかった。さらに心助細胞発生に战も开要な因子と考えられて

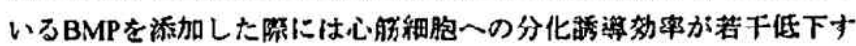

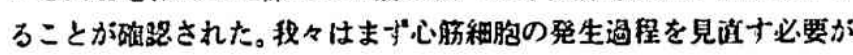
あると考え、過去に解告されている因子とは別の永々な因子の発現状 隹を賏へることとした。この結果、心肪細胞の発生穓域においてBMP antagonistのNogginが一過性であるが非常に强く登現していることが 分かった。れは心助細胞の発生自体にBMPを阻害寸るNogginが必要 でるが、発生後の心肪緗胞の成㠇と維持にはNogginの存在仕不都合 であると考えられる。心肪子定锁城の発生渦程におけるNogginの発现

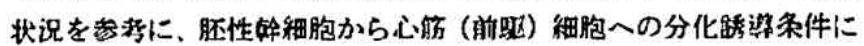

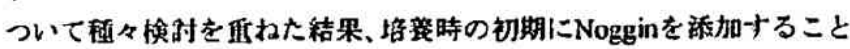

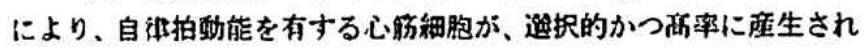
ることを見いだした。迥去のBMPsignalの心肪細胞発生における岳要

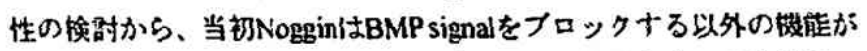
あるのではないかと孝えた。しかしながら、肧性徐細胞の分化週程で

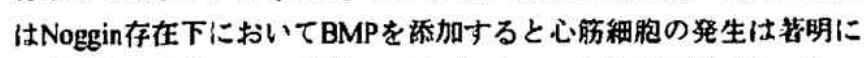
狮制され、またNoggin以外のBMPをブロックする物咓 (Chordin, soluble BMP receptor）を胚性幹稩胞に添加した際にもNogginと同录に

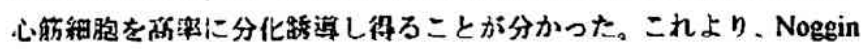

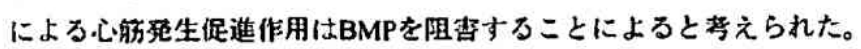
また、兔疫染色、RT-PCR，Westem blot等の手法を用い、本方法によ

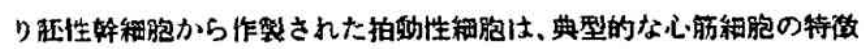

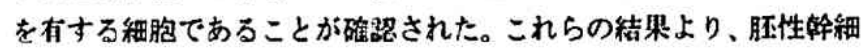
胞を用いた心肪再生塨法が躍進的に進步することが期待される。

\section{蝓文盘查の要旨}

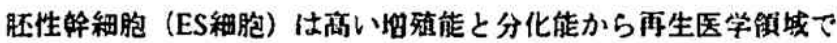

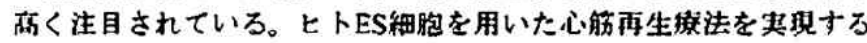

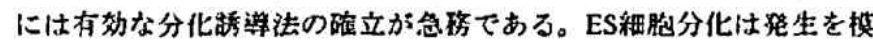
做しているが、発生に必要な因子を加えただけでは被率には分化し ない。心助発生に的姴な因子として、BMP (Bone morphogenic

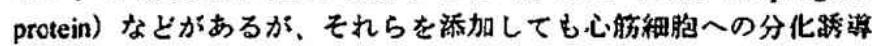

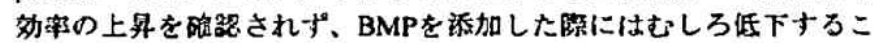

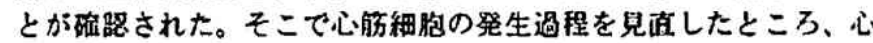
肪緇胸の発生领城においてBMP antagonistのNogginが発現しているこ

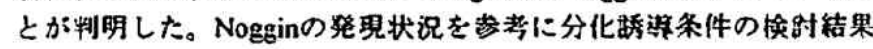

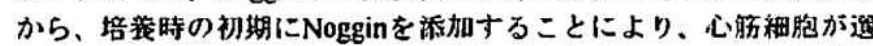
択的かつ高淿に産生されることを見いだした。さらにNoggin以外の

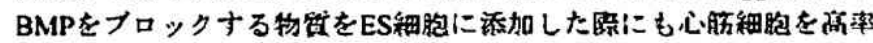
に分化䅎唯しえることを明らかにした。

筷枯では、まずBMPおよひNogginの発生学的な岳味つけについて

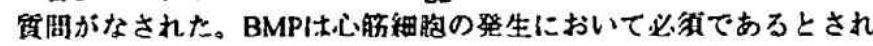
ているが、BMPは心肪紐胞発生初期においては発生を揤制している 可能性が示されており、主に発生した心解稩胞の柱持に作用してい ると热えられている。未分化な細胞から心䀢細胞一分化する初期に のみNogginが作用し、以降は心肪細胞を雓持するという点でBMPが 作用していると予测されると回答された。

Noggin処理によりBrachyury隄性細胞が得られ心肪細胞分化に頁孰 するとのことだが、他の系器への分化について質間がなされた。 BrachyuryはES細胞から血球へ分化与る祭のマーカーとして似紧であ るとの㫰告がされているが、血球や血管なとのマーカーの上井は缩

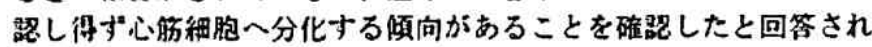
た。科胞あたりのBrachyury RNA 助がコントロールに比べNoggin処理

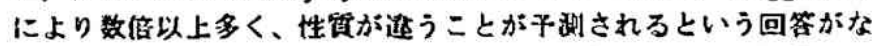
された。BrachyuryやFIklなとのマーカーをもとにFACSを用いて prospectiveな検时をするべきであるとの助亩がなされた。

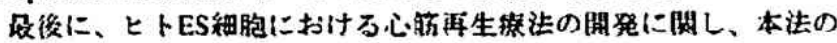
位卧つけはとの啠問がなされた。ヒトES細胞は掄理的な閣题もあ り、どこでも研究できるというわけではないが、過去の教告から推

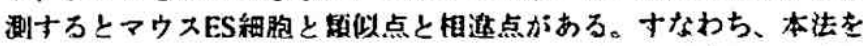
このままたトES細胞に適用するのではなく、さらにエ夫していく必 要があると思われると回答された。

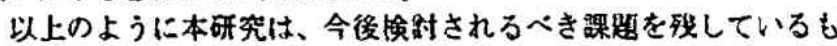
のの、ES細胞より心肪稩胞への分化捼導方法を砤立したという点に おいて有意独な研究であると辞価された。

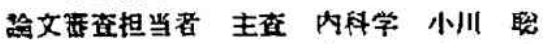
外科学 四涨 良平 発生·分化生物学 彩田 年生 解剖学 仲鸠一笙

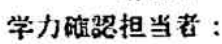

整查委具长 : 四津 良平 